Щоголев Д. С., аспірант

\title{
ОКРЕМІ ПРОБЛЕМИ ВИЗНАЧЕННЯ РОДОВОГО ОБ'СКТА ЗЛОЧИНІВ, ПЕРЕДБАЧЕНИХ РОЗДІЛОМ ХХ КРИМІНАЛЬНОГО КОДЕКСУ УКРАЇНИ
}

\begin{abstract}
Анотація. Стаття присвячена дослідженню проблем визначення родового об'єкта злочинів, передбачених Розділом XX КК України. Розглядаються сучасні погляди науковців на визначення цієї проблеми, аналізується вплив міжнародних актів на формування об'єкта кримінально-правової охорони. Підкреслюється, що Римський статут міжнародного кримінального суду $є$ важливим нормативно-правовим актом міжнародного характеру, який визначає концептуальні засади протидії та запобігання злочинів, що посягають на міжнародний правопорядок. Переглянуто зміст та класифікацію злочинів проти миру, безпеки людства та міжнародного правопорядку, які передбачені Розділом XX КК України. Зокрема, визначено вплив норм міжнародного права на формування родового об'єкта таких злочинів. 3'ясовано, що вирішальне значення у систематизації кримінального законодавства відіграє положення щодо родового об'єкта злочину, яке дає змогу обгрунтувати класифікацію всіх злочинів та відповідних кримінально-правових норм у межах конкретних розділів КК, якими закріплена відповідальність за посягання на тотожні або однорідні суспільні відносини. Визначено, що саме специфіка криміналізації вказаних злочинів, їх конвенційний та бланкетний характер мають бути підставою для їх систематизації, визначення родового об'єкта і, відповідно, їх назви, а також подальшої класифікації за видовим об'єктом. 3 метою уніфікації положень кримінального законодавства 3 міжнародними нормативно-правовими актами необхідно змінити назву Розділу XX відповідно до класифікації, наведеної у Римському статуті, на «Злочини геноциду, агресії, проти людяності та воєнні злочини».

Ключові слова: злочини проти миру та безпеки людства, Римський статут міжнародного кримінального суду, міжнародні злочини.
\end{abstract}

Постановка проблеми. Останніми роками Українська держава зробила чимало важливих кроків. Безумовно, ключовою подією в цьому зв'язку стало підписання та ратифікація Угоди про асоціацію між Україною та Європейським Союзом. Одним iз елементів цієї угоди було бажання України зміцнити міжнародний мир та безпеку, а також залучитися до ефективної багатосторонності та мирного вирішення спорів, зокрема за допомогою тісного співробітництва, з метою досягнення цих цілей в рамках Організації Об'єднаних Націй, ОБСЄ та Ради Європи. На виконання цих положень Україна зобов'язалася забезпечувати поступову адаптацію законодавства України до законодавства Європейського Союзу відповідно до напрямів, визначених у цій угоді. Крім того, статтею 6 Закону України «Про основи національної безпеки» серед пріоритетів національних інтересів визначено інтеграцію України в європейський політичний, економічний та правовий простір.
У ст. 8 зазначеної вище Угоди передбачено, що сторони співробітничають 3 метою зміцнення миру та міжнародного правосуддя шляхом ратифікації та імплементації Римського статуту міжнародного кримінального суду 1998 року та пов’язаних з ним документів.

Водночас Законом України «Про ратифікацію угоди про асоціацію між Україною та Європейським Союзом» щодо цієї статті встановлені певні застереження, зокрема п. 1 визначено, що зобов'язання України щодо ратифікації Римського статуту міжнародного кримінального суду будуть виконані після внесення відповідних змін до Конституції України.

Римський статут міжнародного кримінального суду є важливим нормативно-правовим актом міжнародного характеру, який визначає концептуальні засади протидії та запобігання злочинів, що посягають на міжнародний правопорядок. 3 огляду на це виникає потреба по-новому переосмислити зміст та класифікацію злочинів, передбачених розділом ХХ КК України (злочини проти миру, безпеки людства та міжнародного правопорядку).

Аналіз останніх досліджень і публікацій, в яких започатковано розв'язання цісї проблеми. Значний внесок у розвиток поняття злочинів проти миру, безпеки людства та міжнародного правопорядку, їх місця в системі кримінального законодавства України та визначення родового об'єкта внесли праці В. Базова, Ю. Бауліна, П. Пекаря, В. Поповичука, С. Мохончука, В. Миронової, А. Маєвської, Т. Рияда, М. Сіранта, М. Хавронюка, О. Шамари та ін.

Метою статті $€$ визначення впливу норм міжнародного права на формування родового об' єкта злочинів, передбачених Розділом ХХ КК України.

Виклад основного матеріалу дослідження. Одним із елементів підвищення ефективності законодавства, ліквідації колізій, створення чіткої, заснованої на науковому підгрунті системи нормативно-правових актів є систематизація, що має відбуватися з додержанням алгоритму системно-структурного аналізу. Базовими концептуальними положеннями систематизації є те, що законодавство України про кримінальну відповідальність становить Кримінальний кодекс України, який грунтується на Конституції України та загальновизнаних принципах і нормах міжнародного права.

Міжнародне право нині значно підвищує свою роль у процесах систематизації та криміналізації суспільно небезпечних діянь. Ю. Баулін зазначає, що помітною стає тенденція, за якої у країнах, що додержуються принципів як монізму, так і дуалізму в кримінальному законодавстві, окремі ознаки складу злочину знаходять своє закріплення в приписах некримінального законодавства. Іншими словами, йдеться про поширення 
випадків формулювання ознак складу злочину в бланкетних диспозиціях статей КК України [1, с. 7]. До таких злочинів, беззаперечно, слід віднести і злочини, передбачені Розділом XX КК України, адже підставою їх криміналізації стала ратифікація відповідних положень міжнародно-правових актів. На думку Ю. Бауліна, це пов'язано з процесами глобалізації у різних сферах людської життедіяльності: в економіці, політиці, екології, духовному житті тощо. 3 огляду на це одним із напрямів розвитку сучасного кримінального права має стати прискорення процесів імплементації норм міжнародних договорів у КК України.

На значення міжнародного права для процесів систематизації та криміналізації суспільно небезпечних діянь вказували й інші вчені в галузі кримінального права. Зокрема, Є. Вечерова, відзначаючи відсутність натепер єдиного механізму впливу міжнародного права на згадані вище процеси, акцентує увагу на тому, що характер такого впливу має диференціюватися залежно від того, в якій сфері вчинюється злочин, і максимальний ступінь його впливу доцільно визначити саме серед злочинів проти миру, безпеки людства та міжнародного правопорядку [2, с. 169].

Вирішальне значення у систематизації кримінального законодавства відіграє положення щодо родового об'єкта злочину. Саме особливості цього виду об'єкта дають змогу провести науково обгрунтовану класифікацію всіх злочинів та відповідних кримінально-правових норм, тобто об'єднати ix у межах конкретних розділів КК, якими закріплена відповідальність за посягання на тотожні або однорідні суспільні відносини [3]. В. Тацій слушно зауважує, «така науково обгрунтована систематизація в КК кримінально-правових норм про відповідальність за окремі злочини має важливе значення для застосування цього закону, з' ясування його справжнього змісту, відмежування від суміжних злочинів, а також орієнтування у самому КК» [3, с. 14].

Дослідники проблем кримінальної відповідальності за злочини проти миру, безпеки людства та міжнародного правопорядку відзначають декілька концептуальних проблем, які стосуються підстав виокремлення такої категорії злочинів в окремий розділ КК України, визначення їх родового об'єкта, назви, а також місце розташування в системі особливої частини Кримінального кодексу України.

Питання визначення родового об'єкта злочинів, передбачених розділом XX КК України, а відповідно, і його назви характеризується різноманітністю поглядів на таку проблему та відсутністю нині єдиного концептуального підходу. Цілком ймовірно, що основна причина цього полягає в складності визначення категорії міжнародного злочину в системі міжнародного правопорушення. Доволі грунтовно ці проблеми окреслюються в дослідженні С. Мохончука. Зокрема, ним проведене дослідження, що стосується використання в правовому полі таких понять, як «конвенційні злочини», «кримінальні злочини міжнародного характеру», «злочини, що порушують міжнародний правопорядок», «злочини проти міжнародного права», «злочин згідно із міжнародним правом», «злочин за міжнародним правом» тощо [4, с. 39-41].

Не вступаючи у дискусію з цього питання, лише зазначимо, що нині в теорії кримінального та міжнародного права здебільшого застосовується дворівнева класифікація таких злочинів, а саме «міжнародні злочини» $\mathrm{i}$ «злочини міжнародного характеру».
Злочинами міжнародного характеру визнаються передбачені міжнародними договорами суспільно небезпечні діяння, які не належать до міжнародних злочинів і посягають як на внутрішній державний, так і міжнародний правопорядок. С. Мохончук зазначає, що за своєю юридичною природою більшість 3 них можна віднести до загальнокримінальних злочинів, ускладнених іноземним елементом. Такі злочинні діяння мають транснаціональний характер і найбільш значною їх частиною $€$ порушення норм, які через їх міжнародну небезпеку закріплені у договорах, конвенціях, міждержавних угодах. За цією ознакою подібні злочини кваліфікуються як конвенційні [4, с. 41].

3 огляду на це в науці кримінального права є точка зору, що таку категорію злочинів необхідно вилучити із Розділу ХХ КК України, адже вони не відповідають системі злочинів, що там передбачена, оскільки в них йдеться про міжнародні злочини. На думку С. Махончука, це стосується злочину, передбаченого ст. 446 КК України (піратство), оскільки ступінь суспільної небезпеки та віднесення цього злочину у міжнародному праві до категорії найтяжчих, серйозних злочинів не дають можливості вважати його злочином проти миру та безпеки людства [4, с. 39].

Хоча, на наш погляд, більш грунтовною є точка зору С. Яценка, який вказує на те, що це має стосуватись не лише піратства, а й інших злочинів міжнародного характеру, зокрема посягання на життя представника іноземної держави (ст. 443), злочини проти осіб та установ, що мають міжнародний захист (ст. 444), незаконне використання символіки Червоного Хреста, Червоного Півмісяця, Червоного Кристала (ст. 445) та найманство (ст. 447) [5, с. 816].

Т. Рияд 3 цього приводу висловлює цікаву позицію, що стосується характеристики міжнародного злочину. Зокрема, він зазначає, що саме велика суспільна небезпечність міжнародного злочину відрізняе його від загальнокримінальних злочинів. Кваліфікація загальнокримінальних злочинів входить до компетенції національних судів і розмежовується межами внутрішньодержавного законодавства. На відміну від такої кваліфікації, міжнародний злочин не є результатом суб'єктивної оцінки ситуації з боку окремої держави. Міжнародний злочин визнається таким тільки на підставі міжнародного права і тільки тоді, коли Міжнародний кримінальний суд, Рада Безпеки ООН чи інші міжнародні організації вживають певних заходів 3 реалізації міжнародної відповідальності окремої держави [6, c. 241].

Саме в контексті міжнародних злочинів як різновиду міжнародного правопорушення вчені i намагаються визначити родовий об'єкт цієї категорії злочинів.

Г. Ожегова, вважаючи міжнародний злочин різновидом міжнародного правопорушення, визначає його об'єктом суспільні відносини, що регулюються та охороняються нормами міжнародного права [7, с. 41].

В. Миронова говорить про суспільні відносини, що забезпечують мир, безпеку людства та міжнародний правопорядок. Тобто відносинами, які забезпечують дотримання норм міжнародного права, які охороняють основи існування держав і народів, а також дотримання основних принципів міжнародного миру й безпеки, які в цілому забезпечують мирне врегулювання спорів, є розв'язання конфліктів міжнародними державами [8, c. 22-23].

С. Мохончук, який провів досить грунтовне дослідження кримінально-правової охорони миру та безпеки людства 
в межах докторської дисертації, зазначає, що родовим об' єктом $\epsilon$ суспільні відносини, що складаються в результаті дотримання норм міжнародного права і визначають базові засади існування держав і народів, а також основні принципи забезпечення міжнародного миру і безпеки (мирне вирішення спорів, незастосування сили, недоторканність кордонів, територіальна цілісність, самовизначення народів і невтручання у внутрішні справи інших країн, повага прав людини і виконання міжнародних зобов'язань), що зрештою охороняють умови існування людства. При цьому він звертає увагу на те, що, оскільки систематизація статей в Особливій частині КК України здійснюється за родовим об'єктом, що зумовлюється специфікою суспільних відносин, які охороняються нормами розділу ХХ КК України, то відтак «міжнародний правопорядок» не може розглядатися як складник родового об'єкта, позаяк він є змістовно ширшим за поняття «мир та безпека людства» та співвідноситься з ними як ціле і частина. Міжнародний правопорядок слід розглядати як усю сукупність суспільних відносин, які охороняються системою міжнародного права в цілому: права і свободи людини й громадянина, власність, громадський порядок і безпека, довкілля, певною мірою конституційний устрій держави, мир та безпека людства. Тому посягання на ці блага також можна вважати посяганням на міжнародний правопорядок. У зв'язку 3 цим із метою уникнення термінологічних суперечностей ним запропоновано вилучити поняття «міжнародний правопорядок» із назви розділу ХХ КК України [9, с. 18].

Аналогічної точки зори додержується і О. Шамара, який, визначаючи родовим об'єктом злочинів, передбачених ст. 436447 КК України, життєво важливі інтереси міжнародного співтовариства, обгрунтовує тим самим вилучення з назви Розділу XX Особливої частини КК України «злочинів проти міжнародного правопорядку», при цьому мир та безпеку людства слід розглядати як різновиди таких інтересів і вважати видимими об' єктами злочинів [10, с. 92].

В. Базов, з огляду на властивості родового об'єкта та його складових частин, пропонує виокремити із Розділу ХХ КК України злочини проти миру та воєнні злочини і об'єднати їх у межах окремого розділу Особливої частини КК України під назвою «Злочини проти миру та загальновизнаних правил ведення війни і інших збройних конфліктів (воєнні злочини)», розмістивши його після розділу ХХ КК України. На його думку, таке упорядкування системи Особливої частини КК сприятиме розмежуванню і визначенню родових об'єктів злочинів, а також ретельнішому вивченню і встановленню причин та умов, що призводять до скоєння воєнних злочинів та злочинів проти миру [11, с. 10].

На наш погляд, саме специфіка криміналізації злочинів, передбачених Розділом ХХ КК України, їх конвенційний та бланкетний характер мають виступати підставою для їх систематизації, визначення родового об' єкта і, відповідно, їх назви, а також подальшої класифікації за видовим об'єктом.

Міжнародне право в напрямі класифікації найбільш тяжких злочинів проти людства вже зробило чимало важливих кроків. Серед основних нормативно-правових актів тут слід відзначити Статут Нюрнберзького трибуналу [12], проект Кодексу про злочини проти миру та безпеки людства [13], а також прийнятий Статут Римського МКС [14].

У Статуті Нюрнберзького трибуналу (ст. 6) вперше було визначено приблизну систему міжнародних злочинів, а саме: а) злочини проти миру; б) військові злочини; в) злочини проти людяності. Генеральна Асамблея ООН у грудні 1946 року в спеціальній резолюції підтвердила норми міжнародного кримінального права, викладені в Статуті та реалізовані у відповідних вироках як загальновизнані.

У 1947 році Генеральна Асамблея ООН доручила Комісії міжнародного права скласти проект Кодексу злочинів проти миру і безпеки людства. Комісія прийняла в першому читанні проект цього Кодексу в 1991 р. Він складався з двох своєрідних частин: Загальної та Особливої. Частина друга включала норми про 12 видів злочинів, міжнародно-правових злочинів проти миру і безпеки людства і про злочини міжнародного характеру (наприклад, про наркотизм та про екологічні злочини). Після врахування зауважень, що надійшли від 22 держав, проект був істотно оновлений і прийнятий у другому читанні в 1994 р., особлива частина якого тепер включала п'ять видів злочинів: агресію; геноцид; злочини проти людяності; військові злочини; злочини проти персоналу ООН і дипломатичних осіб [15].

Систематизація міжнародних злочинів знайшла своє продовження також і в статутах міжнародних трибуналів по Руанді та колишній Югославії. Так, відповідно до Статуту Міжнародного трибуналу по Руанді ними визначено геноцид, злочини проти людяності та злочини проти міжнародного гуманітарного права, передбачені ст. 3, загальною для Женевських конвенцій та додаткового протоколу II [16], а в Статуті Міжнародного трибуналу по колишній Югославії ними вбачаються серйозні порушення Женевських конвенцій від 12 серпня 1949 року, порушення законів та звичаїв війни, геноцид, злочини проти людяності [17].

Міжнародне співтовариство довго плекало надії щодо створення постійного суду в межах системи міжнародного правосуддя і починаючи з 1994 р. розпочало перемовини щодо цього. Історичною стала дата 17 липня, коли 120 країн прийняли Римський статут - установчий документ для постійного міжнародного кримінального суду, і з 2002 р. він набув чинності, коли 60 країн ратифікували цей документ.

Діючи на основі Римського статуту, міжнародний кримінальний суд $є$ незалежною міжнародною організацією та не підпорядковується ООН чи іншим структурам.

Римський статут у ст. 5 визначає таку класифікацію міжнародних злочинів: злочини геноциду, злочини проти людяності, воєнні злочини та злочини агресії.

Порівнюючи таку систему і класифікацію із відповідними положеннями Розділу ХХ КК України, насамперед вбачаються різні підходи в частині визначення злочинів проти людяності (які в КК України отримали назву злочини проти людства) та віднесення до них відповідно до КК України і злочинів геноциду. Із наведених вище міжнародних актів можна помітити, що ці поняття завжди розмежовуються і геноцид має самостійне класифікаційне значення.

Вбачається також і той факт, що, на відміну від більш ранніх міжнародних положень, Римський статут використовує поняття злочинів агресії замість поняття злочинів проти миру і розмежовує їх із воєнними злочинами.

Висновки та пропозиції. Рекомендації стосовно міжнародного співробітництва 3 попередження злочинності та кримінального правосуддя, прийняті 14 грудня 1990 року Резолюцією ООН 45/107, визначають необхідність активізувати боротьбу i3 міжнародними злочинами шляхом дотримання та зміцнення 
правопорядку та законності у міжнародних відносинах. Із цією метою передбачено доповнити та в подальшому розвивати міжнародне кримінальне право в повному обсязі зобов'язань, що випливають із міжнародних договорів у цій галузі, та переглянути своє національне законодавство з тим, щоб забезпечити його відповідність положенням міжнародного кримінального права.

Ця рекомендація ООН передбачає необхідність по-новому переглянути структуру Розділу XX КК України, визначити коло суспільних відносин, що нею охороняються і $з$ огляду на це визначити іiі назву. При цьому, на наш погляд, за основу необхідно взяти положення та класифікацію, що застосована в Статуті міжнародного кримінального суду як останнього міжнародного нормативно-правового акта, який, з огляду на кількість країн, що його підписали, отримав статус загального планетарного масштабу.

Таким чином, вважаємо, що родовим об'єктом злочинів, передбачених Розділом ХХ КК України, є суспільні відносини, що забезпечені принципами та нормами міжнародного права, які мають основоположне значення для забезпечення миру, захисту прав людини та життєво важливих інтересів міжнародної спільноти в цілому.

3 метою уніфікації положень кримінального законодавства 3 міжнародними нормативно-правовими актами необхідно змінити назву Розділу XX відповідно до класифікації, наведеної у Римському статуті, на «Злочини геноциду, агресії, проти людяності та воєнні злочини».

\section{Jimepamypa:}

1. Баулін Ю.В. Основні тенденції розвитку сучасного кримінального права України стосовно підстав кримінальної відповідальності. Актуальні проблеми кримінального права України: тези доповідей та наукових повідомлень студентської наукової конференції: X.: 2007. C. 5-8. URL: http://dspace.nlu.edu.ua/ bitstream/123456789/267/1/24.html (дата звернення: 20.01.2018)

2. Вечерова Є.М. Системно-структурний аналіз кримінального законодавства України: до постановки питання. Юридичний науковий електронний журнал. № 2. 2015. С. 168-171.

3. Кримінальне право України: Особлива частина: підручник / Ю.В. Баулін, В.І. Борисов, В.І. Тютюгін та ін.; за ред. В.В. Сташиса, В.Я. Тація. 4-е вид., переробл. і допов. Х.: Право, 2010.

4. Мохончук С.М. Злочини проти миру та безпеки людства: генезис, еволюція, сучасна регламентація у кримінальному праві та законі: монографія. Х.: Право, 2013. 528 с.

5. Науково-практичний коментар до Кримінального кодексу України / С.С. Яценко (ред.). 4-е вид., перероб. та доп. К.: А.С.К., 2006. $848 \mathrm{c}$

6. Рияд Т. Международное преступление и нарушение прав человека: юрисдикция и правовая ответственность. Правова держава. № 13. 2011. C. 241-248.

7. Ожегова Г. Объекты правонарушений в международном праве. Вестник Самарской гуманитарной академии. Серия «Право». № 1. 2007. C. $36-42$.

8. Миронова В.О. Проблеми кримінальної відповідальності за порушення законів і звичаїв війни: монографія. / За заг. ред. д-ра юрид. наук, проф. В.П. Ємельянова. Х.: Право, 2007. 152 с.

9. Мохончук С.М. Кримінально-правова охорона миру та безпеки людства: автореф. дис. ... доктора юрид. наук: 12.00.08. Харків: Нац. юрид. ун-т ім. Ярослава Мудрого, 2014. 39 с.

10. Шамара О.В. Преступления против мира и безопасности человечества: дискуссия в теории уголовного права Украины. Юридическая наука. 2015. № 2. С. 87-93.

11. Базов В.П. Кримінальна відповідальність за порушення законів і звичаїв війни (аналіз складу злочину): автореф. дис. ... канд. юрид. наук: 12.00.08. Харків: Національна юридична академія України імені Ярослава Мудрого, 2009. 22 с.

12. Статут Міжнародного військового трибуналу для суду та покарання головних військових злочинців європейських країн від 08.08.1945 // База даних «Законодавство України» / ВР України. URL: http://zakon5.rada.gov.ua/laws/show/998_201 (дата звернення: 24.01.2018).

13. Проект Кодексу злочинів проти миру та безпеки людства (витяг) 01.01.1995 // База даних «Законодавство України» / ВР України. URL: http://zakon2.rada.gov.ua/laws/show/995_710 (дата звернення: 24.01.2018).

14. Римський статут міжнародного кримінального суду від 16.01.2002 // База даних «Законодавство України» / ВР України. URL: http://zakon3.rada.gov.ua/laws/show/995_588 (дата звернення: 24.01.2018).

15. Борзенков Г.Н., Комиссаров В.С. Курс уголовного права. Особенная часть: в 5 т. Москва: Зерцало, 2002. Т. 5. 470 с.

16. Статут Міжнародного трибуналу по Руанді від 07.07.2009 // База даних «Законодавство України» / ВP України. URL: http:// zakon2.rada.gov.ua/laws/show/995_d65 (дата звернення: 24.01.2018).

17. Статут Міжнародного трибуналу по колишній Югославії (International Criminal Tribunal for the former Yugoslavia). URL: http://www.un.org/ru/law/icty/charter.shtml (дата звернення: 24.01.2018).

Щеголев Д. С. Отдельные проблемы определения родового объекта преступлений, предусмотреных разделом ХХ Уголовного кодекса Украины

Аннотация. Статья посвящена исследованию проблем определения родового объекта преступлений, предусмотренных разделом ХХ УК Украины. Рассматриваются современные взгляды ученых на определение данной проблемы, анализируется влияние международных актов на формирование объекта уголовно-правовой охраны. Подчеркивается, что Римский устав международного уголовного суда является важным нормативно-правовым актом международного характера, который определяет концептуальные основы противодействия и предотвращения преступлений, посягающих на международный правопорядок. Пересмотрены содержание и классификация преступлений против мира, безопасности человечества и международного правопорядка, предусмотренных разделом XX УК Украины. В частности, определено влияние норм международного права на формирование родового объекта таких преступлений. Установлено, что решающее значение в систематизации уголовного законодательства играет положение относительно родового объекта преступления, которое позволяет обосновать классификацию всех преступлений и соответствующих уголовно-правовых норм в рамках конкретных разделов УК, которыми закреплена ответственность за посягательство на тождественные или однородные общественные отношения. Определено, что именно специфика криминализации указанных преступлений, их конвенционный и бланкетный характер должны выступать основанием для их систематизации, определения родового объекта и, соответственно, их названия, а также дальнейшей классификации по видовым объектам. С целью унификации положений уголовного законодательства с международными правовыми актами необходимо изменить название раздела $\mathrm{XX}$ в соответствии с классификацией, приведенной в Римском уставе, на «Преступления геноцида, агрессии, против человечности и военные преступления».

Ключевые слова: преступления против мира и безопасности человечества, Римский устав международного уголовного суда, международные преступления. 
Shchegolev D. Separate problems of determination of the general object of crimes provided by the Section of the XX Criminal Code of Ukraine

Summary. The article is devoted to the study of the problems of determining the generic object of crimes under Section XX of the Criminal Code of Ukraine. The modern views of scientists on the definition of this problem are considered, the influence of international acts on the formation of the object of criminal law protection is analyzed. Considering the Rome Statute of an international criminal court, it is an important regulatory legal act of an international character, which defines the conceptual basis for countering and preventing crimes encroaching on the international legal order. The content and classification of crimes against peace, the security of mankind and the international legal order, as provided for by Section XX of the Criminal Code of Ukraine, has been revised. In particular, the influence of the norms of international law on the formation of the generic object of such crimes is defined. It has been established that decisive importance in systematization of criminal legislation is played by the provision regarding the generic object of a crime, which makes it possible to substantiate the classification of all crimes and relevant criminal law norms within specific sections of the Criminal Code, which fix the responsibility for encroaching on identical or homogeneous social relations. It was determined that the specificity of criminalization of these crimes, their conventional and blanket nature should be the basis for their systematization, definition of a generic object and, accordingly, their names, as well as further classification by type object. In order to unify the provisions of criminal law with international legal acts, it is necessary to change the name of Section $\mathrm{XX}$ in accordance with the classification given in the Rome Statute on "Crimes of genocide, aggression, against humanity and war crimes".

Key words: crimes against peace and security of mankind, Rome Statute of the International Criminal Court, international crimes. 